\title{
Analysis of drug resistance to HIV-1 protease using fitness function in genetic algorithm
}

\author{
A Harishchander $^{1 *}$, S Senapati ${ }^{2}$, D Alex Anand ${ }^{1}$ \\ From First International Science Symposium on HIV and Infectious Diseases (HIV SCIENCE 2012) \\ Chennai, India. 20-22 January 2012
}

\section{Motivation}

Analysing the potential organic molecule for inhibiting HIV-1 protease against its drug resistance by predicting its fitness using Genetic Algorithm will enhance research in the discovery of identifying the potential lead for inhibiting the aspartyl protease of HIV type I.

\section{Methods}

Drug resistance is predicted for all FDA approved HIV-1 protease inhibitors and organic leads synthesized by Dr. Deeb and Dr. Godzari with wild type and mutant strains of subtype B. Initially the structural feature of HIV-1 protease with the inhibitor complex has been anlysed on the basis of "Binding Energies". Finally the fitness function in Genetic Algorithm was used for optimizing the inhibition of specific organic lead with three fold cross validation.

\section{Results}

Structural data mining performed by the fitness function in Genetic Algorithm gave pattern identities between HIV-1 protease (wild type and mutants) of sub type B against organic leads and FDA approved inhibitors of HIV-1 protease. Genetic Algorithm gives "80\% Accuracy" for wild type inhibition and "75\% Accuracy" for mutant inhibition in the final optimization by fitness function.

\section{Conclusion}

Organic leads have greater affinity than the FDA approved inhibitors (specifically Mol-23 which has good correlation with pIC50 and $\mathrm{H}$ Bonding descriptors). I84V mutant still remains resistant to both FDA approved Inhibitors and Organic Molecules. In future the dynamics of the molecule will be analysed for all

\footnotetext{
* Correspondence: harishchander.a@gmail.com

${ }^{1}$ Department of Bioinformatics, Sathyabama University, Chennai, India

Full list of author information is available at the end of the article
}

FDA approved protease Inhibitors and potential organic leads with the wild type and mutant proteases of HIV type I.

\section{Author details \\ ${ }^{1}$ Department of Bioinformatics, Sathyabama University, Chennai, India. ${ }^{2}$ Department of Biotechnology, Indian Institute of Technology Madras, Chennai, India.}

Published: 4 May 2012

doi:10.1186/1471-2334-12-S1-O7

Cite this article as: Harishchander et al: Analysis of drug resistance to HIV-1 protease using fitness function in genetic algorithm. BMC Infectious Diseases 2012 12(Suppl 1):O7.
Submit your next manuscript to BioMed Central and take full advantage of:

- Convenient online submission

- Thorough peer review

- No space constraints or color figure charges

- Immediate publication on acceptance

- Inclusion in PubMed, CAS, Scopus and Google Scholar

- Research which is freely available for redistribution

Submit your manuscript at www.biomedcentral.com/submit

\section{() Biomed Central}

